\title{
Decolorization of Azo Dyes using Dried Biomass of Bacillus cereus RC1 and Kocuria kristinae RC3
}

\author{
Rajeswari Uppala (D), Krishnan Sundar (D) and Azhaguchamy Muthukumaran* \\ Department of Biotechnology, Kalasalingam Academy of Research and Education, Krishnankoil - 626 126, \\ Tamil Nadu, India.
}

\begin{abstract}
The dried biomass of Bacillus cereus RC1 and Kocuria kristinae RC3 were evaluated for their efficacy in decolorizing two azo dyes, Eriochrome Black T and Amido Black 10B, respectively in batch system. Further, the influence of the initial dye concentration, contact time, concentration of biomass, temperature and $\mathrm{pH}$ on the dye decolorization efficacy of the bacterial biomass was studied. The findings suggested the profound dye adsorption efficacy of the bacterial biomass towards the test dyes, in aqueous solution. In addition, the experimental findings also showed the effect of the process parameters on the extent of biosorption. The bacterial biomass of $B$. cereus RC1 $(200 \mathrm{mg} / \mathrm{I})$ exhibited the highest dye uptake (EBT) of $72.66 \%$ in an aqueous solution of $\mathrm{pH} 7.0$ (at $35^{\circ} \mathrm{C}$ ) with an initial dye concentration of $45 \mathrm{mg} / \mathrm{I}$ with a contact time of $60 \mathrm{~min}$. In case of $K$. kristinae RC3 $(300 \mathrm{mg} / \mathrm{I})$, the optimum decolorization (AB) of $91.27 \%$ was achieved at $35^{\circ} \mathrm{C}$ with an initial dye concentration of 15 $\mathrm{mg} / \mathrm{l}$ and $\mathrm{pH}$ value of 7.0. The optimal contact time was found to be $90 \mathrm{~min}$. Thus, the biomass of $B$. cereus RC1 and $K$. kristinae RC3 may be employed to facilitate the treatment of dye contaminated water in an economical and eco-friendly way.
\end{abstract}

Keywords: Decolorization, adsorption, Eriochrome black T, Amido black 10B, Biomass, Bacillus cereus.

*Correspondence: a.muthukumaran@klu.ac.in

(Received: 18 June 2019; accepted: 02 August 2019)

Citation: Rajeswari Uppala, Krishnan Sundar and Azhaguchamy Muthukumaran, Decolorization of Azo Dyes using Dried Biomas of B. cereus RC1 and Kocuria kristinae RC3, J Pure App/Microbiol., 2019; 13(4):1969-1976. https://doi.org/10.22207/JPAM.13.4.08

C The Author(s) 2019. Open Access. This article is distributed under the terms of the Creative Commons Attribution 4.0 International License which permits unrestricted use, sharing, distribution, and reproduction in any medium, provided you give appropriate credit to the original author(s) and the source, provide a link to the Creative Commons license, and indicate if changes were made. 


\section{INTRODUCTION}

Synthetic dyes are extensively employed in numerous sectors like pharmaceutical, textiles, cosmetics, food and paper industries. However, the improper discharge of these dyes, as a result of the inefficient dyeing process, is a menace to the natural ecosystem. The uncontrolled release of dye effluent in the aqueous environment affects the water quality by reducing dissolved oxygen concentration and penetration of sunlight. In addition, they are also lethal to the aquatic life forms as well as human health ${ }^{1}$. Some dyes and their degraded by-products also possess mutagenic and carcinogenic property ${ }^{2}$.

Among the synthetic dyes, the dyes containing azo function $(\mathrm{N}=\mathrm{N}-)$ represents one of the most concerning dyes due to their high toxicity and carcinogenic nature ${ }^{3}$. The carcinogenic azo dye, Eriochrome Black T (EBT) is among the most widely employed textile dye commonly used for dyeing silk, wool, and nylon fibers. It is also employed as an indicator in the assessment of metal cations ${ }^{4}$. Another azo dye widely used in textile industries is Amido black $10 B(A B)$. $A B$ is used in the dyeing of natural (silk, wool, and cotton) as well as synthetic fibers like rayon and polyester. The dye is also used in staining of proteins in biochemical tests, in inks, paints, leather and plastics industries. $A B$ is known to damage the human respiratory system and cause inflammation to skin and eyes ${ }^{5}$. Hence, development of cost-effective and eco-friendly adsorbent to effectively segregate and eliminate these dyes from industrial effluents has become a necessity in minimizing the pollution of water bodies and its toxic effects to humans as well as other life forms ${ }^{3}$.

Considering the problems associated with these dyes, numerous physical and chemical approaches including oxidation, ozonation, membrane filtration, coagulation are extensively studied for their ability to remove these dyes from wastewater. However, these techniques suffer from many constraints, such as high-costs and generation of unwanted toxic secondary pollutants ${ }^{6}$. Hence, in recent years the biological processes have received much attention as a better alternative for the remediation of dyecontaminated water bodies.

The process of biosorption is regarded as a promising way for the removal of recalcitrant pollutants (metals and dyes) from water bodies. Numerous organisms including algae, bacteria, fungi, and plants have been documented for their ability to remove and mineralize dyes. Biomaterials derived from fungi, algae, bacteria and agricultural by-products are known to preferably bind to various pollutants ${ }^{7}$. Numerous species of bacteria including Aeromonas ${ }^{1}$, Citrobacter ${ }^{8}$, Bacillus ${ }^{9}$, Klebsiella ${ }^{10}$ and Pseudomonas ${ }^{11}$ have exhibited substantial decolorization of textile dyes.

Microbial biomass has also been documented for their ability to accumulate a range of dyes and heavy metals. Based on the report of Aksu et al. (2006), the dried biomass of Rhizopus arrhizus was used as biosorbent to effectively remove Gemazol Turquise Blue-G reactive dye ${ }^{12}$. Though numerous studies have been executed on the dye decolorization potential of bacteria, reports on the use of non-pathogenic dried bacterial biomass are still limited. The advantages associated with the use of heat-treated bacterial biomass include less production time, inexpensive and ease in handling. Various researchers have used dead bacterial cells as an effective alternative to synthetic adsorbent of dyes. Busi et al. (2016) documented the efficient adsorption of azo dyes, Eriochrome black T, Acid Red 26 and Trypan blue using biomass (dried) of Aeromonas hydrophila $\mathrm{RC}^{13}{ }^{13}$. In another report, Du et al. (2012) documented the ability of Pseudomonas sp. biomass in decolorizing Acid Black $172^{11}$. The biomass of Corynebacterium glutamicum was successfully employed as a biosorbent for the decolorization azo dye, Reactive Black 5 (RB5) ${ }^{14}$. The presence of carbonyl, amino, hydroxyl and phosphate groups imparts a negative charge to the cell wall of the bacteria. Consequently, the cationic environmental pollutants get adsorbed on the bacterial surface or taken up by either active or passive transport mechanisms ${ }^{7}$.

Due to simplicity in the process, low operating cost, high efficiency and environmental benign characteristics, adsorption is commonly adopted for remediation of an aqueous environment. However, the use of suitable adsorbent and process parameters is the key to achieve optimal removal of the pollutants ${ }^{4}$. This study was conducted to study the ability of dried biomass of $B$. cereus RC1 and K. kristinae RC 3 in decolorizing two azo dyes, Eriochrome Black T 
and Amido Black 10B respectively. Further, the effect of varying environmental factors on the decolorization was studied to attain maximum dye removal from the aqueous solution.

\section{MATERIALS AND METHODS}

The bacterial cultures, B. cereus RC1 and $K$. kristinae RC3 were isolated from water samples collected from textile effluent discharge located at Tirupur, Tamil Nadu, India ${ }^{15,16}$. The media components and the dyes used in the present study were procured from Hi-Media Laboratories Pvt. Ltd, Mumbai, India. The azo dyes, Eriochrome black $T(E B T)$ and Amido black 10B (AB) were dissolved in distilled water to obtain the required concentration.

\section{Bacterial growth and biomass yield}

The bacterial cultures were cultivated in $250 \mathrm{ml}$ of liquid medium containing peptone $(10 \mathrm{~g} / \mathrm{l})$, sucrose $(20 \mathrm{~g} / \mathrm{l}), \mathrm{KH}_{2} \mathrm{PO}_{4}(1 \mathrm{~g} / \mathrm{l}), \mathrm{MgSO}_{4} \cdot 7 \mathrm{H}_{2} \mathrm{O}(0.5$ $\mathrm{g} / \mathrm{l})$ and $\mathrm{NaNO}_{3}(1 \mathrm{~g} / \mathrm{l})$. The flasks were incubated with shaking (at $150 \mathrm{rpm}$ ) at $37^{\circ} \mathrm{C}$ and $\mathrm{pH} 7$ for $24 \mathrm{~h}$, The increase in cell density was recorded at a regular interval of $4 \mathrm{hrs}$, at $520 \mathrm{~nm}$. The growth curves of bacterial isolates were generated and the corresponding biomass yield was determined ${ }^{13}$.

\section{Preparation of biomass}

After incubation for $24 \mathrm{hrs}$, the culture broth of $B$. cereus RC1 and $K$. kristinae RC3 were subjected to centrifugation (6000 rpm) at $4^{\circ} \mathrm{C}$ for $10 \mathrm{~min}$. The cell pellet was collected, rinsed thrice with $0.9 \% \mathrm{NaCl}$ and oven-dried for $24 \mathrm{hrs}$ at $80^{\circ} \mathrm{C}$. The resulting dried biomass was employed for the subsequent assays ${ }^{17}$.

\section{Dye adsorption study}

The dye decolorization ability of $B$. cereus RC1 and $K$. kristinae RC3 dried biomass was executed in $250 \mathrm{ml}$ conical flasks containing 100 $\mathrm{mg} / \mathrm{l}$ of each dye, EBT and $A B$ suspended in $100 \mathrm{ml}$ of distilled water. After the incubation period, the optical density of the dye solution was measured at $523 \mathrm{~nm}$ and $620 \mathrm{~nm}$ for EBT and $A B$, respectively. The percentage decolorization for each treatment was calculated ${ }^{18}$.

\section{Effect of different parameters on dye decolorization}

The process parameters including dye concentration, adsorbent dose, biomass contact time, temperature and $\mathrm{pH}$ which may influence the dye adsorption capacity of the dried bacterial biomass were tested using batch experiments.

\section{Effect of initial dye concentration}

To investigate the effect of initial dye concentration on the adsorption efficacy of the bacterial biomass, the dried bacterial biomass $(100 \mathrm{mg} / \mathrm{ml})$ was dispensed in the dye solution containing a varying concentration of dye ranging from $10-100 \mathrm{mg} / \mathrm{l}$. The medium was maintained at $\mathrm{pH} 7.0$ and incubated at $37^{\circ} \mathrm{C}$ in a shaking incubator (150 rpm). After $24 \mathrm{hrs}$ of incubation, the dye concentration was determined ${ }^{19}$.

\section{Effect of biomass concentration}

To determine the effect of biomass dosage on the dye decolorization efficacy, the biomass ranging from $100-600 \mathrm{mg} / \mathrm{ml}$ was supplemented in the dye solution containing $100 \mathrm{mg} / \mathrm{l}$ of the test dye. After incubation of $24 \mathrm{~h}$ at $37^{\circ} \mathrm{C}$, the decrease in the color intensity of the reaction mixture was measured spectrophotometrically ${ }^{20}$.

\section{Effect of contact time}

To determine the effect of contact time on the decolorization efficacy of the bacterial biomass, a volume of $100 \mathrm{mg} / \mathrm{ml}$ of the biomass was inoculated in distilled water supplemented with $100 \mathrm{mg} / \mathrm{l}$ of the dye. The medium was incubated in a shaker at $37^{\circ} \mathrm{C}$ for $150 \mathrm{~min}$. The reduction in the dye concentration was recorded at every 30 min interva $\left.\right|^{19}$.

\section{Effect of temperature}

The role of temperature on the decolorization process was determined based on the protocol of Siddhi \& Disha (2017) with few modifications. The reaction mixture containing 100 $\mathrm{mg} / \mathrm{l}$ each of the dye and the bacterial biomass was incubated at varying temperatures ranging from $30-60^{\circ} \mathrm{C}$. The dye solution was maintained at $\mathrm{pH} 7$ and a temperature of $37^{\circ} \mathrm{C}$. After $24 \mathrm{~h}$ of incubation, the \% decolorization of the test dyes was assessed ${ }^{21}$.

\section{Effect of $\mathrm{pH}$}

To study the effect of different $\mathrm{pH}$ on the decolorization efficacy of the bacterial biomass, the reaction mixture containing $100 \mathrm{mg} / \mathrm{l}$ of each test dye were prepared separately. The dye solution was adjusted to different $\mathrm{pH}$ ranging from 5- 9 using $1 \mathrm{~N} \mathrm{HCl}$ or $1 \mathrm{~N} \mathrm{NaOH}$. A volume of 100 $\mathrm{mg} / \mathrm{l}$ of the bacterial biomass was supplemented into the dye solution and the reaction mixture was incubated overnight at $36^{\circ} \mathrm{C}$ in a shaker ${ }^{22}$. The concentration of dyes, before and after the 
adsorption was recorded by recording the change in optical density at $523 \mathrm{~nm}$ for EBT and $620 \mathrm{~nm}$ for $A B$. All the assays were conducted in triplicate.

\section{RESULTS}

\section{Bacterial growth and biomass yield}

As depicted in the growth curve of

Fig. 1, a gradual increase in the cell density and biomass yield in both the bacteria, $B$. cereus RC1 and $K$. kristinae RC3 were observed with increase in incubation time. After $24 \mathrm{hrs}$ of incubation, the optical density of RC1 and RC3 were found to be $0.43 \pm 0.032$ and $0.35 \pm 0.01$, respectively. Further, the total bacterial biomass concentration extracted from the broth culture of RC1 and RC3 on $24 \mathrm{hrs}$ of incubation were quantified to be $18.35 \pm 0.47 \mathrm{mg}$ and $16.42 \pm 0.18 \mathrm{mg}$, respectively (Fig. 1).

Effects of different process parameters on dye decolorization efficacy

Effect of dye dosage and biomass concentration

A gradual increase in percentage adsorption by the biomass of $B$. cereus RC1 could be observed with the increase in the concentration
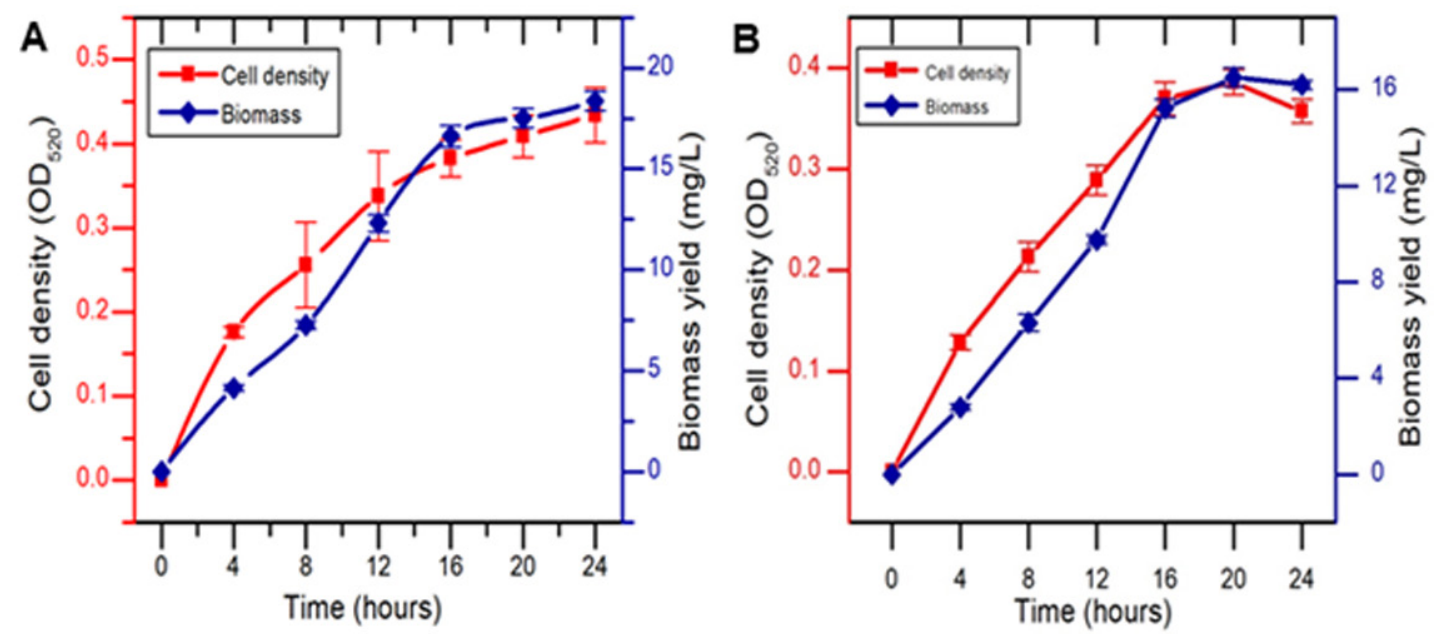

Fig. 1. Bacterial growth and biomass yield of $B$. cereus RC1 (A) and $K$. kristinae RC3 (B) recorded for a period of $24 \mathrm{hrs}$.
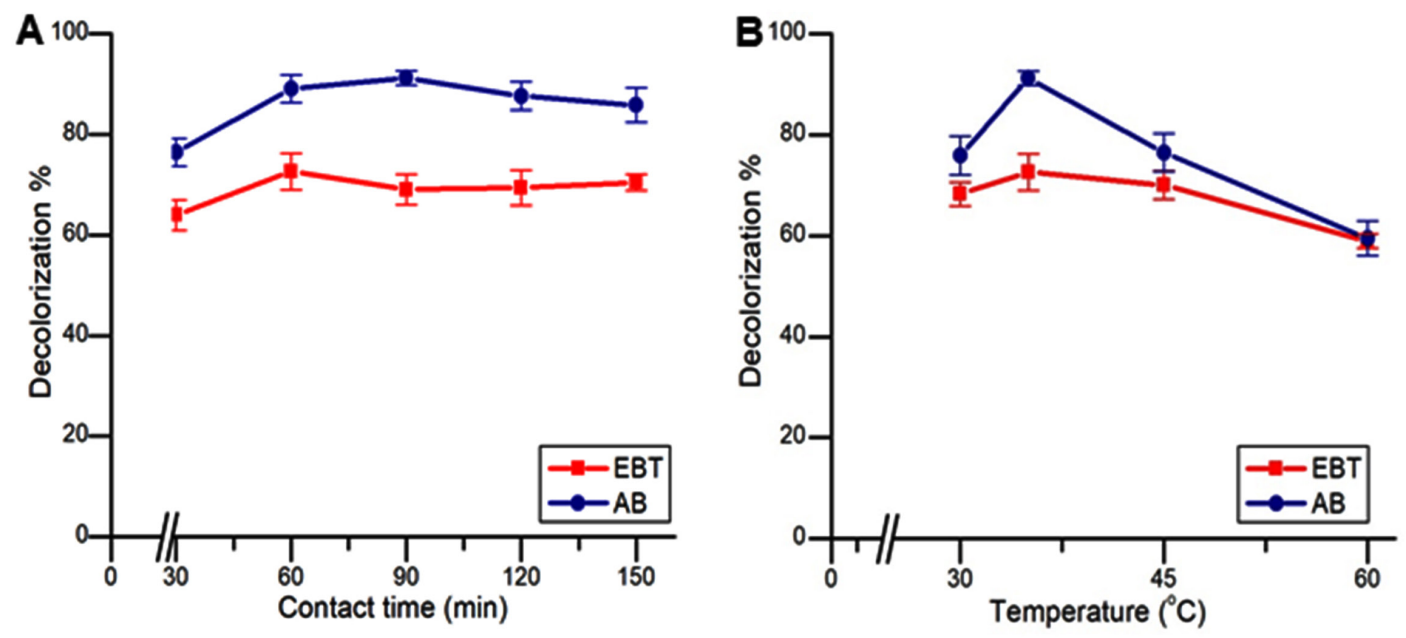

Fig. 2. (A) Effect of dye concentration on decolorization percentage of dyes EBT and $A B$ by $B$. cereus RC1 and $K$. kristinae RC3, respectively. (B) Effect of biomass on decolorization percentage of dyes EBT and AB by $B$. cereus RC1 and $K$. kristinae RC3, respectively. 
of EBT from $20-45 \mathrm{mg} / \mathrm{l}$ which was followed by a steady decrease with the further increase in dye concentration up to $90 \mathrm{mg} / \mathrm{l}$ (Fig. $2 \mathrm{~A}$ ). However, in the case of $K$. kristinae RC3, a gradual decrease in the \% biosorption of $A B$ with the corresponding increase in the dye concentration was observed. The highest \% biosorption of 64.38 $\pm 2.65 \%$ and $88.76 \pm 2.36 \%$ by RC1 and RC3 were observed at $45 \mathrm{mg} / \mathrm{l}$ and $15 \mathrm{mg} / \mathrm{l}$ dye concentration, respectively.

The effect of varying biomass concentration of both the bacteria on the removal of the dye, EBT and $A B$ is shown in Fig. 2B. At the dye concentration of $100 \mathrm{mg} / \mathrm{l}$, there was not much change on the percent decolorization with an increase in biosorbent concentration for both $B$. cereus RC1 and K. kristinae RC3. However, the percent removal of the EBT by $B$. cereus RC1 was notably lower as compared to percentage decolorization of $\mathrm{AB}$ by $K$. kristinae $\mathrm{RC} 3$ as presented in Fig. $2 \mathrm{~b}$. The maximum percentage removal of EBT by $72.66 \pm 3.62 \%$ was achieved at the biomass concentration of $200 \mathrm{mg} / \mathrm{l}$ whereas the maximum percentage removal of $A B$ by 89.07 $\pm 2.81 \%$ was obtained $300 \mathrm{mg} / \mathrm{l}$ of biomass (Fig. 2).

\section{Effect of contact time and temperature}

As depicted in Fig. $3 \mathrm{~A}$, a gradual increase in the percent of decolorization of both EBT and $A B$ was observed with increase in contact time, which was followed by a slight decrease up to 150 min of incubation. In the case of EBT, the maximum decolorization percent of $72.66 \pm 3.62 \%$
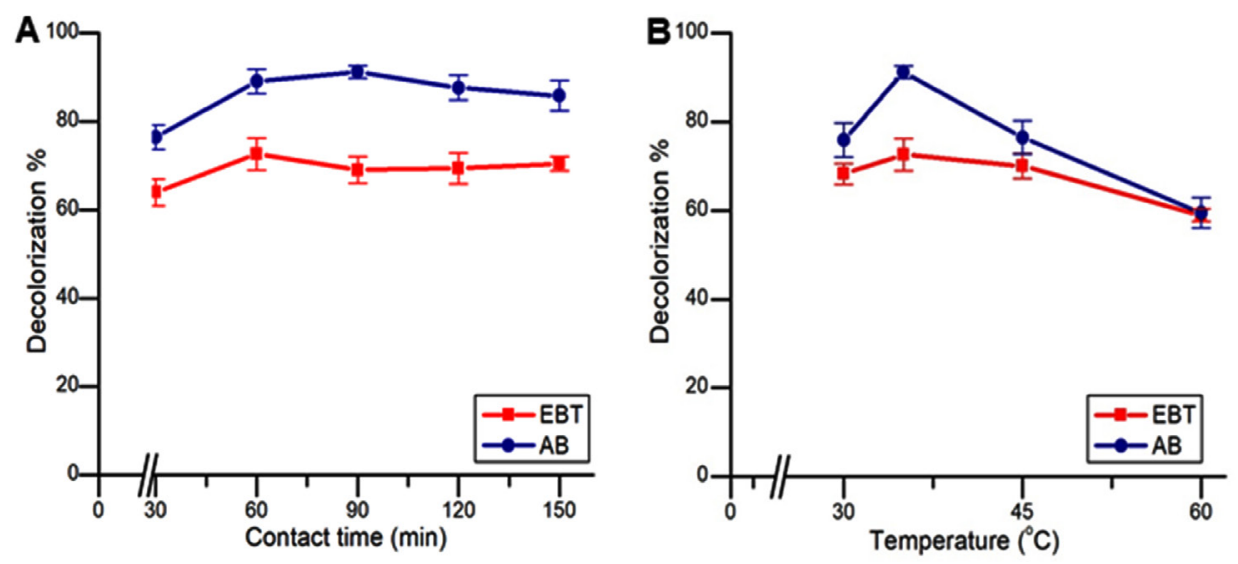

Fig. 3. (A) Effect of contact time on decolorization percentage of dyes EBT and AB by $B$. cereus RC1 and $K$. kristinae $R C 3$, respectively. (B) Effect of temperature on decolorization percentage of dyes EBT and $A B$ by $B$. cereus $R C 1$ and K. kristinae $\mathrm{RC}$, respectively.

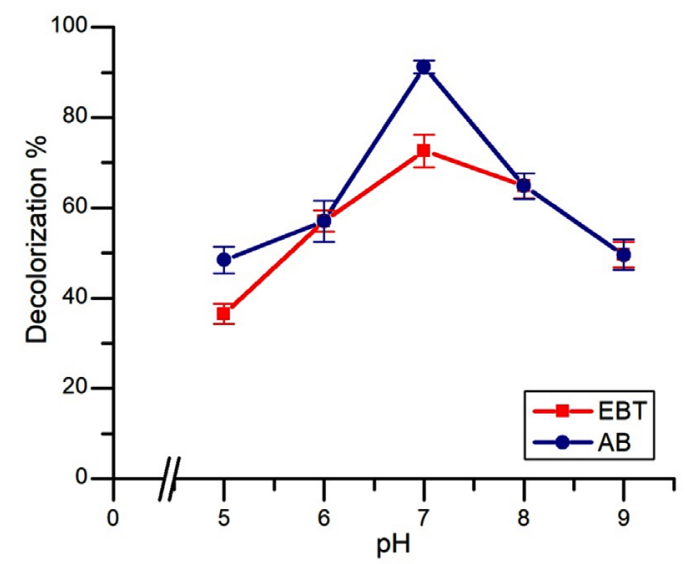

Fig. 4. Effect of $\mathrm{pH}$ on decolorization percentage of dyes EBT and AB by $B$. cereus RC1 and K. kristinae RC3, respectively. was observed at a contact time of 60 min which decreased gradually from 90 to $150 \mathrm{~min}$. Similarly, in the case of $A B$, the maximum decolorization was attained at a contact time of 90 min with a decolorization percent of $91.27 \pm 1.40 \%$ and then gradually decreases to $85.85 \pm 3.36 \%$ at $150 \mathrm{~min}$, as shown in Fig. $3 A$.

Fig. 3B represents the effect of temperature on the biosorption of EBT and $A B$ at the biosorbent dosage of $100 \mathrm{mg} / \mathrm{l}$. With the gradual increase in temperature from $30^{\circ} \mathrm{C}$ to $35^{\circ} \mathrm{C}$, a significant increase in the percent of decolorization for both the dyes was achieved. At $35^{\circ} \mathrm{C}$, EBT and $\mathrm{AB}$ exhibited the highest percentage decolorization of $72.66 \pm 3.62 \%$ and $91.27 \pm 1.40 \%$, respectively. However, the dye removal capacity gradually decreased with increase in temperature 
(Fig. 2B). At $60^{\circ} \mathrm{C}$, the percentage biosorption of the dyes, EBT and $A B$ were found to be $58.97 \pm$ $1.37 \%$ and $59.48 \pm 3.42 \%$, respectively.

\section{Effect of pH}

As presented in Fig. 4, a significant variation in the percentage decolorization was seen at different $\mathrm{pH}$. There was a steady increase in the percent removal of EBT from $36.5 \pm 2.18 \%$ at $\mathrm{pH} 5$ to $72.66 \pm 3.62 \%$ at $\mathrm{pH}$ 7. This was followed by a decrease in percentage decolorization by $49.61 \pm 2.18 \%$ at $p H 9$. Similarly, in the case of $A B$, the increase in $\mathrm{pH}$ from 5 to 7 was accompanied by an increase in percentage removal from $48.45 \pm 2.97 \%$ to $91.27 \pm 1.40 \%$, respectively at a dye concentration of $100 \mathrm{mg} / \mathrm{l}$. The maximum decolorization of $72.66 \pm 3.62 \%$ and $91.27 \pm 1.40 \%$ for EBT and $A B$ respectively, was observed at $\mathrm{pH} 7$.

\section{DISCUSSION}

The dried bacterial biomass of $B$. cereus RC1 and $K$. kristinae RC3 were successfully employed for the removal of EBT and $A B$ from aqueous solution. These bacterial isolates have been reported for their decolorization potential in live conditions at different physiochemical conditions and results were further confirmed by response surface methodology ${ }^{15,16}$. The ability of bacterial biomass to interact with dyes is governed by various factors. Some of the most important factors influencing the performance of biological dye removal are the chemical structures of the dyes, type of biomass, process conditions including dye concentration, biomass dosage, $\mathrm{pH}$, temperature and contact time ${ }^{7}$. Hence, the adsorption studies were performed under different process parameters to achieve maximum decolorization. Both the test bacteria showed significant dye decolorizing efficacy in vitro. However, the percentage removal of EBT by $B$. cereus RC1 was found to be considerably lower as compared to the percentage removal of $A B$ by K. kristinae RC3.

The bioadsorption efficacy is directly governed by the dye concentration and the availability of binding sites for the dye molecules on the adsorbent surface. Hence, the unavailability of adsorption sites usually decreases the decolorization efficiency ${ }^{23}$. The initial dye dosage significantly affects the biosorption efficacy of the dyes. A gradual increase in percentage decolorization of EBT with the increase in concentration was followed by a steady decrease with the further increase in dye concentration from $45 \mathrm{mg} / \mathrm{l}$. However, in the case of $K$. kristinae $\mathrm{RC3}$, a continuous decrease in the percentage biosorption of $A B$ was observed with increasing dye concentration from $15 \mathrm{mg} / \mathrm{l}$. Hence, $45 \mathrm{mg} / \mathrm{l}$ and $15 \mathrm{mg} / \mathrm{l}$ of EBT and $A B$ were determined to be the maximum dye dosage that could be adsorbed on $100 \mathrm{mg} / \mathrm{l}$ of the test bacterial biomass. The decrease in the dye decolorization efficacy with the subsequent increase in dye dosage might have resulted due to the saturation of biomass surface and unavailability of adsorption sites. Wang et al. (2013) presented the dye absorption ability of Bacillus species YZU1. The effect of varying concentration of Reactive Black 5 on the overall decolorization efficacy was also documented. At a concentration of $50 \mathrm{mg} / \mathrm{l}$ of Reactive Black 5 , $90 \%$ decolorization was observed within $60 \mathrm{~h}$ of incubation while at $300 \mathrm{mg} / \mathrm{l}$ the time required was $120 \mathrm{~h}^{9}$.

From an economic point of view, optimization of biosorbent dosage is required to obtain a high rate of dye elimination with low biosorbent dose. Usually, the efficiency of dye decolorization in an aqueous medium increases with the corresponding increase in the adsorbent dosage. This results due to the availability of more surface area and binding sites for the dye molecules ${ }^{23}$. The optimum biomass concentration resulting in the maximum adsorption of $100 \mathrm{mg} / \mathrm{I}$ of dye was found to be $200 \mathrm{mg} / \mathrm{l}$ and $300 \mathrm{mg} / \mathrm{l}$ for $B$. cereus RC1 and K. kristinae RC3, respectively. The equilibrium state observed in case of both bacteria strains indicated that further increase in biomass dosage did not exert much effect on the absorption of the dyes. According to the report of Nacera \& Aicha (2006), the increase in the biosorption of methylene blue onto the biomass of Streptomyces rimosus corresponds to the increase in the quantity of the bacterial biomass used in the batch experiment ${ }^{20}$.

Contact time is also a major factor that regulates the adsorption of dissolved substance onto the biomass surface, thereby influencing the dye decolorization process. In the case of EBT, a rapid biosorption of the dye was seen at the initial $60 \mathrm{~min}$ of exposure to the biomass. Thereafter, the rate of biosorption gradually 
reached equilibrium at $90 \mathrm{~min}$. Similarly, in the case of $A B$, the maximum decolorization was attained at a contact time of $90 \mathrm{~min}$. The high degree of adsorption indicates the affinity of the bacterial biomass for the test dyes. In a similar report, on supplementation of the Rhizopus arrhizus biomass, a rapid decolorization of dye was observed within 15-20 min of exposure; thereafter the process of adsorption was less significant. Within a contact time of 30 and $60 \mathrm{~min}$, respectively, the maximum percentage decolorization of Congo red dye and Fast Red A was attained ${ }^{19}$.

Another important factor affecting the biosorption process is the temperature. High temperature increases the surface active sites and kinetic energy of the dye molecules, subsequently resulting in enhanced biosorption ${ }^{23}$. However, the high temperatures are also reported to physically damage the biosorbent. In case of passive or physical adsorption, the dye molecules interact with the biomass via a weak bond. In such a case, the exposure to high temperature might break the bonds which subsequently lead to desorption of the dye. In this study, a significantly lower percentage of decolorization was seen with an increase as well as a decrease in temperature from $35^{\circ} \mathrm{C}$. Hence, for both the dyes, EBT and $A B$ the optimum temperature for dye removal was determined to be $35^{\circ} \mathrm{C}$. Similarly in another report, the temperature of the dye solution was found to significantly affect the biosorption capacity of Corynebacterium glutamicum biomass. In support of the present finding, $35^{\circ} \mathrm{C}$ was determined to be the most favored temperature for the biosorption of Reactive Black 5 by $C$. glutamicum in aqueous solution $^{14}$.

The dye removal efficacy of a bio-sorbent is also significantly governed by the $\mathrm{pH}$ of the environment. The protonated dried biomass of $C$. glutamicum has been earlier used as a biosorbent for the removal of Reactive Red $4^{24}$. Generally, a solution with high $\mathrm{pH}$ facilitates adsorption of cationic dye as compared to anionic ones. In contrast, anionic dyes are adsorbed more efficiently at low $\mathrm{pH}^{23}$. As the $\mathrm{pH}$ decreases, the $\mathrm{H}^{+}$ion concentration increases; therefore cell surface holds $\mathrm{H}^{+}$ions rather than other cations $\mathrm{s}^{25}$. For both $E B T$ and $A B$, the optimum $\mathrm{pH}$ required for maximum decolorization was determined as $\mathrm{pH}$ 7. The percentage decolorization was found to decrease at $\mathrm{pH}$ lower than and higher than $\mathrm{pH} 7$ suggesting that the dye-loaded biomass could be regenerated at $\mathrm{pH}>7$ or $<7$. In a similar study, Won et al. (2005) reported the impact of pH on the dye removal efficacy of the biomass of $C$. glutamicum. The dried biomass showed an increase in dye uptake with a decrease in $\mathrm{pH}$ and a negligible dye uptake was observed at $\mathrm{pH}>7^{24}$.

\section{CONCLUSION}

The present study is one of the very few communications on the utilization of dried bacteria biomass for the decolorization of dyes in aqueous solution. The findings also represent the initial report on the removal of two azo dyes, EBT and $A B$ in batch systems using dried $B$. cereus RC1 and $K$. kristinae RC3 as a biosorbent. However, the affinity of dried biomass of $K$. kristinae RC3 towards $A B$ was found to be relatively stronger to the binding of $B$. cereus RC1 biomass for EBT. Further, it was also found that the variation in the initial dye dose, adsorbent dose, contact time, temperature and $\mathrm{pH}$ significantly influenced the dye uptake efficiency of the biomass. The bacterial biomass of $B$. cereus $\mathrm{RC} 1$ and $K$. kristinae RC3 exhibited the highest dye uptake of $72.66 \%$ and $91.27 \%$, at $35^{\circ} \mathrm{C}$ and $\mathrm{pH} 7$. Hence, the bacterial biomass might be employed as an eco-friendly and cost-effective approach for the remediation of water bodies contaminated with azo dyes.

\section{ACKNOWLEDGEMENTS}

The authors acknowledged Kalasalingam Academy of Research and Education for providing the research facility.

\section{CONFLICTS OF INTEREST}

The authors declare that there is no conflict of interest.

\section{AUTHORS' CONTRIBUTION}

All authors made a substantial contribution to the work and approved the final manuscript.

\section{FUNDING}

None.

\section{DATA AVAILABILITY}

The datasets generated and/or analysed 
during the current study are available from the corresponding author on reasonable request.

\section{ETHICS STATEMENT}

This article does not contain any studies with human participants or animals performed by any of the authors.

\section{REFERENCES}

1. Chen KC, Wu JY, Liou DJ,Hwang SC. Decolorization of the textile dyes by newly isolated bacterial strains. J. Biotechnol., 2003; 101(1): 57-68. https://doi. org/10.1016/S0168-1656(02)00303-6

2. Imran M, Crowley DE, Khalid A, Hussain S, Mumtaz MW, Arshad M. Microbial biotechnology for decolorization of textile wastewaters. Rev. Environ. Sci. Bio/Technol., 2015; 14(1): 73-92. https://doi.org/10.1007/s11157014-9344-4

3. Saratale RG, Gandhi SS, Purankar MV, Kurade MB, Govindwar SP, Oh SE, Saratale GD. Decolorization and detoxification of sulfonatedazo dye C.I. Remazol Red and textile effluent by isolated Lysinibacillus sp. RGS. J. Biosci. Bioeng., 2013; 115(6): 658-667. https://doi. org/10.1016/j.jbiosc.2012.12.009

4. Khalid A, Zubair M, Ihsanullah A. Comparative study on the adsorption of eriochrome black T dye from aqueous solution on graphene and acid-modified graphene. Arab J. Sci. Eng., 2018; 43(5): 2167-2179. https://doi.org/10.1007/s13369-017-2543-x

5. Angelova R, Baldikova E, Pospiskova K, Safarikova M, Safarik I. Magnetically modified sheaths of Leptothrix sp. as an adsorbent for Amido black 10B removal. J. Magn. Magn. Mater., 2017; 427: 314- 319. https:// doi.org/10.1016/j.jmmm.2016.10.094

6. Khan R, Bhawana P, Fulekar M. Microbial decolorization and degradation of synthetic dyes: a review. Rev. Environ. Sci. Bio., 2013; 12: 75-97. https://doi. org/10.1007/s11157-012-9287-6

7. Vijayaraghavan K,Yun YS. Bacterial biosorbents and biosorption. Biotechnol. Adv., 2008; 26(3): 266-291. https://doi.org/10.1016/j.biotechadv.2008.02.002

8. Wang HJ, Su Q, Zheng XW, Tian Y, Xiong XJ, Zheng TL. Bacterial decolorization and degradation of the reactive dye Reactive Red 180 by Citrobacter sp. CK3. Int. Biodeterior. Biodegradation, 2009; 63: 395-399. https://doi.org/10.1016/j.ibiod.2008.11.006

9. Wang ZW, Liang JS, Liang Y. Decolorization of Reactive Black 5 by a newly isolated bacterium Bacillus sp. YZU1. Int. Biodeterior Biodegradation, 2013; 76: 41-48. https://doi.org/10.1016/j.ibiod.2012.06.023

10. Zablocka-Godlewska E, Przystas W, Grabinska-Sota E. Dye Decolourisation Using Two Klebsiella Strains. Water Air Soil Pollut, 2015; 226: 2249. https://doi. org/10.1007/s11270-014-2249-6

11. Du LN, Wang B, Li G, Wang S, Crowley DE, Zhao YH. Biosorption of the metal-complex dye Acid Black 172 by live and heat-treated biomass of Pseudomonas sp. strain DY1: kinetics and sorption mechanisms. J. Hazard Mater., 2012; 205-206: 47-54. https://doi. org/10.1016/j.jhazmat.2011.12.001
12. Aksu Z, Cagatay SS. Investigation of biosorption of Gemazol Turquise Blue-G reactive dye by dried Rhizopus arrhizus in batch and continuous systems. Separ. Purif. Tech., 2006; 48(1): 24-35. https://doi. org/10.1016/j.seppur.2005.07.017

13. Busi S, Chatterjee R, Rajkumari J, Hnamte S. Ecofriendly biosorption of dyes and metals by bacterial biomass of Aeromonas hydrophila RC1. J. Environ. Biol., 2016; 37(2): 267-274.

14. Vijayaraghavan K,Yun YS.Utilization of fermentation waste (Corynebacterium glutamicum) for biosorption of Reactive Black 5 from aqueous solution. J. Hazard Mater., 2007; 141(1): 45-52. https://doi.org/10.1016/j. jhazmat.2006.06.081

15. Uppala R, Sundar K, Muthukumaran A. Response Surface Methodology Mediated Optimization of Textile Azo Dye, Eriochrome Black T Decolorization by Bacillus cereus RC1. Desalin. WATER Treat, 2017; 81: 242-251. https://doi.org/10.5004/dwt.2017.21190

16. Uppala R, Sundar K, Muthukumaran A. Response Surface Methodology Mediated Optimization of Decolorization of Azo Dye Amido Black 10B by Kocuria kristinae RC3. Int. J. Environ. Sci. Technol., 2018; 1-12. https://doi.org/10.1007/s13762-018-1888-3

17. Guendouz S, Khellaf N, Zerdaoui M. et al. Biosorption of synthetic dyes (Direct Red 89 and Reactive Green 12) as an ecological refining step in textile effluent treatment Environ. Sci. Pollut. Res., 2013; 20: 3822. https://doi.org/10.1007/s11356-012-1314-1

18. Ali NF, El-Mohamedy RSR. Microbial decolourization of textile waste water. J. Saudi Chem. Soc., 2012; 216: 117-123. https://doi.org/10.1016/j.jscs.2010.11.005

19. Salvi NA, Chattopadhyay S. Biosorption of Azo dyes by spent Rhizopus arrhizus biomass. Appl. Water Sci., 2017; 7(6): 3041-3054. https://doi.org/10.1007/ s13201-016-0417-0

20. Nacera Y, Aicha B. Equilibrium and kinetic modeling of methylene blue biosorption by pretreated dead Streptomyces rimosus: effect of temperature. Chem. Eng. J., 2006; 119(2-3): 121-125. https://doi. org/10.1016/j.cej.2006.01.018

21. Siddhi MI, Disha D. Bioremediation of Azo Dye: Eriochrome Black $\mathrm{T}$ by the novel organism Bacillus lentus. Biosci. Discov., 2017; 8(4): 771-775.

22. Lalnunhlimi S, Krishnaswamy V. Decolorization of azo dyes (Direct Blue 151 and Direct Red 31) by moderately alkaliphilic bacterial consortium. Braz. J. Microbiol., 2016; 47(1): 39-46. https://doi.org/10.1016/j. bjm.2015.11.013

23. Seow TW, Lim CK. Removal of dye by adsorption: a review. Int. J. Appl. Eng. Res., 2016; 11(4): 2675-2679.

24. Won SW, Choi SB, S, YY. Interaction between protonated waste biomass of Corynebacterium glutamicum and anionic dye Reactive Red 4. Colloids Surf. A Physicochem Eng. Asp., 2005; 262: 175-180. https://doi.org/10.1016/j.colsurfa.2005.04.028

25. Argun YA, Karacali A, Calisir U, Kilinc N, Irak $\mathrm{H}$. Biosorption method and biosorbents for dye removal from industrial wastewater: a review. Int J. Adv. Res., 2017; 5(8): 707-714. https://doi.org/10.21474/ IJAR01/5110 